\title{
A PATH ANALYSIS OF THE IMPACTS OF VALUE TRANSFER ABOUT FOREST ECOLOGICAL SERVICE FROM UPPER WATERSHED OF HUNHE ON WATER SUPPLY IN SHENYANG CITY IN CHINA
}

\author{
JIANG, Y. Q. - CHEN, K. ${ }^{*}$ - CHEN, T. F. - LI, X. T. \\ College of Economics and Management, Shenyang Agricultural University \\ Shenyang 110866, China \\ *Corresponding author \\ e-mail: chenkeyaya@163.com \\ (Received $8^{\text {th }}$ Mar 2017; accepted $7^{\text {th }}$ Jun 2017)
}

\begin{abstract}
The ecological service (ES) of soil and water conservation that is provided by the forest ecosystems in the upper basin of Hunhe river has some movement in certain space, which has an important influence on water supply in Shenyang city in China. From the perspective of forest ES transfer, it works out the ecological service value of transferring in the upstream of Hunhe river towards Shenyang city from 2010 to 2014 with the help of Buffer and Intersect of ArcGIS9.3, and the path analysis is used to explore the impact of the ecological service value (ESV) of transferring in the upstream of Hunhe River Basin on the water supply in Shenyang city. The results demonstrate that firstly total values of transferring from 2010 to 2014 adds up to 5.647 billion RMB, and secondly the ecological service of soil and water conservation has positive external effects on the water supply in Shenyang city by the surface water, groundwater and chemical oxygen demand. It can be seen that it explains the mechanism of action about the impact of transfer value of forest ES in the upper watershed on the water supply in the lower basin, which provides the theoretical foundation to the quantitative analysis of value transferring of forest ES and has an important proof of payment for ecological services of river basin in the theory.
\end{abstract}

Keywords: path analysis; ecological service (ES); transfer value; water supply; Hunhe River Basin

\section{Introduction}

It is well known that human well-being depends on a variety of ecosystem services (ES) provided by nature, ranging from supporting services and provisioning services to regulating services and cultural services. Ecosystems face various pressures resulting from urbanization and increasing population. Especially, the availability and quality of water for many regions in China have become more and more threatened by shortage and pollution. China's per capita water is less than $25 \%$ of the world's per capita level. According to the statistics by the Ministry of Water Resources, there are more than 400 cities in 655 cities in China, which have water shortage of 0.16 billion $\mathrm{m} 3 / \mathrm{d}$, especially severe water shortage in Beijing and Tianjin. As a result of frequent drought, extreme climate change, and more than $50 \%$ of rivers and lakes contaminated, the lack of water supply becomes more and more serious (Liao et al., 2016). And fortunately, it has been increasingly recognized that shortage and pollution of water are strongly influenced by forests. The forest is playing an important role in regulating water quantity and purifying water quality. Ecologists argue that riparian forest is widely regarded as temporary reservoir capturing and processing energy to provide water resources for human beings and maintain various ecological functions. In order to maintain ecological service function in river basin, payment for watershed ecosystem services (PWES) has 
been used to encourage riparian residents from upstream to protect water resources in many countries. For example, the hydropower company funds afforestation in upstream in Costa Rica, and Irrigation Association of Kauka River Basin in Colombia pays fee for forest from upstream to regulate river runoff. Those measures for tree planting and conservation of vegetation are implemented by the payment for watershed ecosystem service to regulate and purify water resource (Zhen, 2006). Therefore, the relationship between forest service value transfer and water is a critical issue.

The services of ecological systems and the natural capital stocks are very critical for the planet's life-support system. They contribute to human welfare, both directly and indirectly, and therefore represent part of the total economic value of the planet (Costanza, 1997). Ecosystem services have being an important concept widely used by ecologists since the 1990s, some scholars have divergent views on the concept of ecosystems services. Ecosystem services are the conditions and processes that natural ecosystems and their constituent species can be used to sustain and meet human survival (Daily, 1997). Costanza defines ecosystem services are that the benefits that humans derive from ecosystems (1997). Ecosystem services refer to the ability of ecosystems to provide a variety of products and services to humans in the Millennium Ecosystem Assessment (MA) (2003). To a certain degree, Wallace agrees with the definition identified by MA, but there are some differences. He stresses that ecosystem process is not the ecosystem service but the production mode of ecosystem services (2007). The definition of ecological services is different among many scholars, it should be defined according to the specific purpose (Zhang, 2012). The ecological service system should be regarded as an entirety, its ecological service functions are interrelated and interacted each other under certain conditions. The concept of ecological service proposed by MA would be adopted in this paper, it classifies the ecosystem serviceswhich function of water purification and water regulation provides the theoretical basis to analyze the impact of watershed forest on water resources.

For a long time, ecosystem services are seen as inexhaustible and free public services, it causes the scarcity of ecological service supply and excessive consumption of ecological services (Egoh et al., 2007). Ecological assets per capita are scare in China, it is an urgent for the natural resource management and ecological compensation to fully evaluate the value of ecological services (ESV) (Xie et al., 2015). The evaluation of ESV is broadly regarded as a useful tool to monetize and measure ecological services. In recent years, many scholars have used static evaluation methods to assess ESV. The contribution of global ecosystems to human welfare is assessed by the static equilibrium model (Dou, 2003). This model usually uses shadow prices and shadow values to estimate the total ESV, but it is based on the assumption that the value of ecosystem services is limited by its direct and indirect impact on market value so that it can be underestimated (Xie, 2011). There are some shortcomings for the accuracy of the simulation results in the biodiversity model due to simplified assumptions and lack of uniform evaluation indicators ( $\mathrm{Li}$ et al., 2013). Traditionally, cost-benefit analysis, firmly grounded in economic theory, is always a major tool to assess ESV, although it is restricted to the need for the monetised inputs. Some economists believe that the core of valuation for resource, environment and ES is the consumers' preferences. At present, the Contingent Valuation Method (CVM) is also a major tool to assess the non-use value of environmental goods and ES (Carson, 2000) by the respondents' willingness to pay (WTP) or willingness to accept (WTA). In 1947, Ciriacy-Wantrup proposed by direct inquiry to understand the respondents 'willingness to pay for public goods and to 
compensate the ecological environment, and then estimate the economic values of public goods and ES (Portney, 1994). Xu takes Liaohe River Basin as a research object and calculates WTP and WTA of the respondents among the residents and analyzes the disparity by using CVM (2015). The close-ended questionnaire and open-ended questionnaire are basic survey techniques for the CVM, but the evaluation result of the two techniques have been controversial, which main argument is that the former obtained WTP higher than the latter. Hanemann argues that the reason of the difference between the two technologies is that respondents' cognition for ES and public environmental goods (1994). So the ESV estimated by CVM are characteristic of subjectivity and greater deviation. As these models mentioned above statically or subjectively evaluate the ESV, they are not suitable to assess the ESV in river basin, considering that the values of some forest ES is flowing and transferring through a certain medium in the space (Qiao et al., 2011).

There are two main methods for evaluation of forest ES, namely, the value evaluation method and material evaluation method $(\mathrm{Hu}, 2007)$. Xiao evaluates qualitatively their economic values of forest ES from 2006 to 2011 by the market value method and production cost method (2014). The disadvantages of these two methods are difficult prediction about the level of ecosystem supply, misunderstanding of the link between the evaluation object and the marketable commodity and difficulty of cost statistics. While the assessment of forest ESV by material evaluation method is based on the existing unit area of ESV multiplied by the corresponding area, and the unit area value of forest ESV is calculated by the Net primary productivity (NPP). Ecosystem services are directly related to the biomass. The productivity and service value of ecosystems is estimated by a series of simplified models based on large-scale remote sensing information. It provides the method for measure of ESV, which has higher accuracy (Paula, 2012). It is common to establish the relationship between forest parameters and the Geographic information system (GIS) (Huang, 2015). Although there are several popular application software that are available in the market such as GRASS GIS, SAGA, gvSIG, ArcGIS have been widely adopted in many fields such as business, scientific research and resource management. ArcGIS is the software of spatial information analysis, it could be not only used to collect data, store data, analyze data and monitor the spatial changes of forest areas, but also measure transferring value of interregional ES, and analyze the impact of different ES. Environmental value transfer is commonly defined as the transposition of monetary environmental values estimated at one site through market-based or nonmarket-based economic valuation techniques to another site (Brouwer, 2000). Environmental value transfer as the procedure estimated on the unobserved monetary value has been widely used, ranging from water quality management to forest management (Luken, 1992; Bateman, 1995). Though the value transfer technique is widely applied in developed countries, it is seldom used in the developing countries, due to the lack of ES valuation expertise (Chaikumbung et al., 2016). The forms and driving factors of value transfer analyzed are necessary supplement to the studies of ES evaluation in China (Fan et al., 2007). Take Weigan river basin in China as an example, it is a significant attempt to do the value transfer estimation of SE by building transfer assessment model of ESV and suing ArcGIS9.3 buffer and overlay analysis platform. The results indicate that ESV has increased continuously from the upstream to the downstream during twenty-two years (Qiao et al., 2011). Besides, value transfer also contributes to determining ecological compensation standard and forming different levels of these in a particular situation (Chen et al., 2014). 
The forest is the key to clean water. A high proportion of the Nation's freshwater resources originate from forests. The relation between forest and water also remains controversial. In the past, there was the assumption that forest not only can maximize water yield, but also regulate seasonal flows and improve water quality. Although the forest is not to significantly increase downstream water yield, the critical role of forest covering upper watershed for ensuring water supply and the delivery of high-quality water has been confirmed (Bruijnzeel, 2004; Calder, 2007; Van et al., 2007). The role of forest in regulating stream flow and groundwater are very effective through interception and evaporation of precipitation from the tree canopies and transpiration from the foliage, and then transportation by litter layer and soil layer (Zhou et al., 2002). In addition to these ecological services, purifying water is also significant by trapping or filtering other water pollutants to alleviate the sediment in water bodies. For instance, the broad-leaf forest ecosystems in the upstream of Jinshui river basin in China make their most significant contribution to regulate the $\mathrm{PH}$ value and alleviate various physical-chemical concentrations so as to cleanse water (Bu et al., 2010). The forests in the upstream is maintaining water flows during the dry season and cleansing water supply, which could provide water-quality resources for residents in downstream. The existing literatures only analyze the direct impacts of forest in the upstream of the basin on water resources, and its indirect effects cannot be further analyzed. Path analysis provides the effective method to study the direct and indirect impacts of forest in the upstream on water resource of the downstream. In 1972, the path analysis method was proposed by Wright. Path analysis is commonly regarded as a multivariate statistical technique, which is used to analyze the relations between two variables, and describe the impact of independent variable on dependent variable. Compared with the multiple regression model, path analysis can explain the direct and indirect effects of independent variable on dependent variable ( $\mathrm{Li}$ et al., 2011). In addition, value transfer of forest resources in the upstream is not marketed and thus their value to water is often ignored in development decision. The complicated relationships are always a hot issue between forest and water in the river basin ( $\mathrm{Li}$ et al., 2001), but water supply in the downstream influenced by value transfer of forest SE from the upper watershed is seldom studied. So the importance of ES value transfer in the upstream to water in the downstream will be discussed in the paper. Path analysis is adopted to analyze and reflects the direct effect and indirect effect about forest of ES Value Transfer in the upstream of Hunhe on Water Supply in Shenyang City.

Based on the facts mentioned above, from the perspective of forest ES transfer, forest ES value transfer from upstream is calculated with ArcGIS9.3 buffer and overlay analysis platform from 2010 to 2014, and then the effects of forest ES value transfer on water supply in Shenyang city cluster can be studied using the path analysis. The objectives of this research are: ( $i$ ) to measure forest transfer value in both upstream and Shenyang city, and (ii ) to analyze the influence of forest value transferred on water supply in Shenyang city by the path analysis. To accomplish the first objective the study performed the following tasks: (1) calculation of forest ESV in the upstream and in Shenyang city respectively, (2) determination of transfer radius and transfer scope, (3) construction of forest ESV transfer assessment model. 


$$
-471-
$$

\section{Definition of forest ES transfer types in river basin}

Forest ecosystem has a variety of ES functions, covering gas regulation, climate regulation, water regulation, soil formation, water conservation, water purification and so on. But it plays an important part of water regulation, water purification and water and soil conservation for forest ES in the river basin. It is highly definite that transfer scopes, influencing factors and features are various among different ecosystem services, on the basis of the definition of transfer types about forest ecosystem service in river basin (Groot, 2002) (Table 1). A variety of ES may be transferring in space, covering climate regulation, water conservation, soil formation and disposal of waste in the forest ecosystem. It is in river basin that forests have been recognized as a ES carrier, which water regulation, water purification, and soil and water conservation could not only be transferred in space, but also their ecological values are gradually decreased with increasing distance of space.

\section{Study area}

Hunhe River Basin lies between Fushun and Dashiqiao and crosses four cities: Shenyang, Anshan, Dengta, Haicheng, covering around $11480 \mathrm{~km}^{2}$ (Figure 1). The upstream and Shenyang city in Hunhe River Basin is demarcated by Da Huofang reservoir. The upstream refers to three counties, including QingRMB, Xinbin, Fushun, while Shenyang city covers five districts: Sujiatun, Tiexi, Shenhe, Heping and Hunnan, covering 5.06 million of people. Shenyang has the semi-humid temperate continental climate, its average temperature of 8.3 , its annual rainfall reaches $500 \mathrm{~mm}$, its annual frost-free period is about 183 days, its forest cover rate is only $28 \%$.

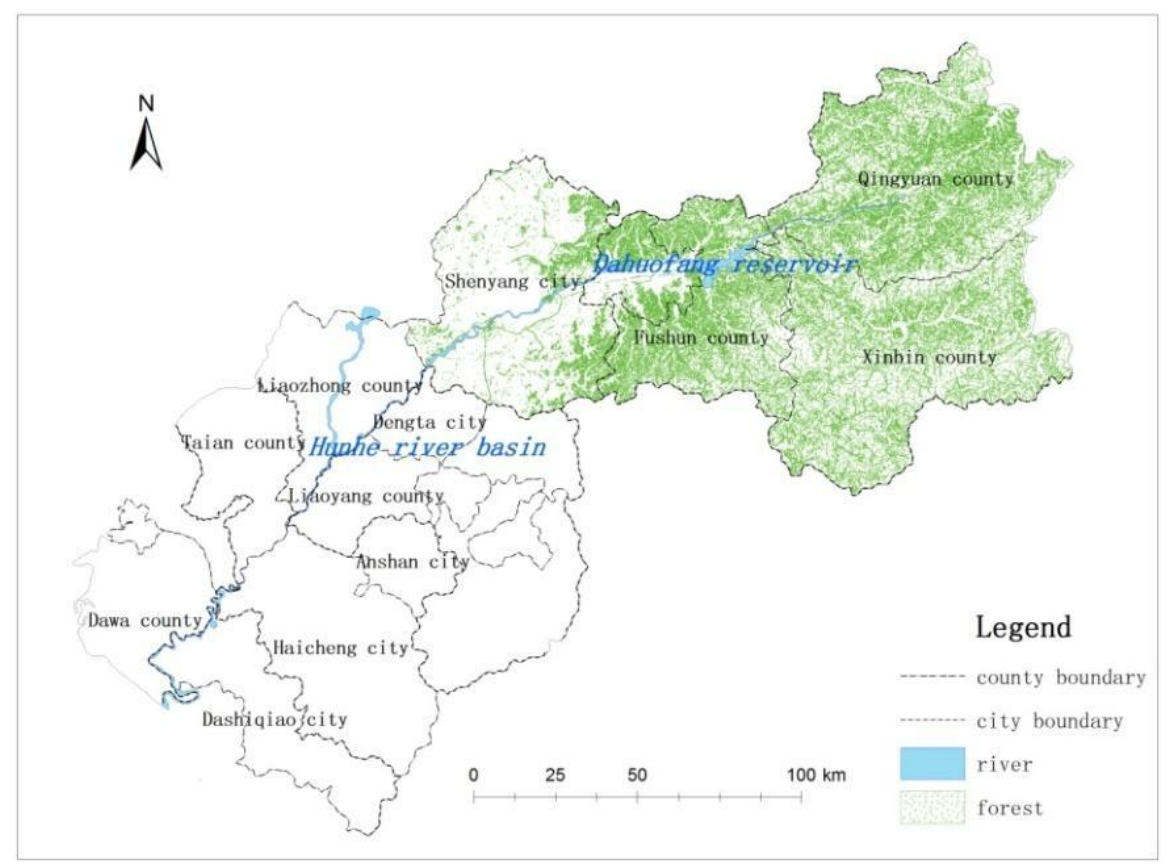

Figure 1. Forest resources distribution between upstream and Shenyang city in Hunhe River Basin 


$$
-472-
$$

Table 1. Transfer scopes, influencing factors and transfer features of different ecosystem services

\begin{tabular}{|c|c|c|c|}
\hline $\begin{array}{c}\text { Ecosystem } \\
\text { service }\end{array}$ & $\begin{array}{c}\text { Transfer } \\
\text { scope / km }\end{array}$ & Influencing factors & Transfer characteristics \\
\hline Gas regulation & $10^{2} 10^{4}$ & $\begin{array}{c}\text { The regulation of } \mathrm{O}_{2}, \mathrm{CO}_{2} \\
\text { and } \mathrm{SO}_{2}\end{array}$ & $\begin{array}{l}\text { With air as medium, } \\
\text { attenuation in the } \\
\text { circulation }\end{array}$ \\
\hline $\begin{array}{l}\text { Climate } \\
\text { regulation }\end{array}$ & $1010^{3}$ & $\begin{array}{l}\text { Albedo coefficient, heat } \\
\text { capacity and other } \\
\text { properties }\end{array}$ & $\begin{array}{l}\text { With air as medium, } \\
\text { planar attenuation in the } \\
\text { circulation }\end{array}$ \\
\hline Water regulation & $1010^{2}$ & $\begin{array}{l}\text { The mesoclimate and other } \\
\text { factors }\end{array}$ & $\begin{array}{l}\text { With air as medium, } \\
\text { planar and linear } \\
\text { attenuation gradually }\end{array}$ \\
\hline Soil formation & - & $\begin{array}{l}\text { Plants, animals, } \\
\text { microorganisms and the } \\
\text { forces of nature }\end{array}$ & $\begin{array}{l}\text { The flow and attenuation } \\
\text { does not occur generally }\end{array}$ \\
\hline $\begin{array}{c}\text { Water } \\
\text { conservation }\end{array}$ & $1010^{2}$ & Forest vegetation, soil, etc & $\begin{array}{l}\text { According to the linear } \\
\text { flow }\end{array}$ \\
\hline $\begin{array}{l}\text { Soil and water } \\
\text { conservation }\end{array}$ & $10^{2}$ & $\begin{array}{c}\text { Plant roots and the forest } \\
\text { vegetation }\end{array}$ & $\begin{array}{l}\text { With soil vegetation as } \\
\text { medium, planar } \\
\text { attenuation gradually }\end{array}$ \\
\hline Water purification & $1010^{2}$ & $\begin{array}{l}\text { The biological and } \\
\text { physical chemistry of } \\
\text { water and vegetation }\end{array}$ & $\begin{array}{l}\text { With water, forest and } \\
\text { soil as medium, planar } \\
\text { attenuation gradually }\end{array}$ \\
\hline $\begin{array}{l}\text { Water content } \\
\text { regulationdisaster } \\
\text { prevention }\end{array}$ & $1010^{2}$ & $\begin{array}{l}\text { The degree of vegetation } \\
\text { structure to flood and } \\
\text { rainstorm }\end{array}$ & $\begin{array}{l}\text { Planar and linear } \\
\text { attenuation gradually }\end{array}$ \\
\hline Nutrient cycling & $10^{3}$ above & $\begin{array}{l}\mathrm{C}, \mathrm{N}, \mathrm{S}, \mathrm{P} \text { and other } \\
\text { nutrients to life }\end{array}$ & $\begin{array}{l}\text { Irregular, but no } \\
\text { attenuation generally }\end{array}$ \\
\hline Pollination & $10^{-2} 10^{2}$ & $\begin{array}{l}\text { The atmosphere, water, or } \\
\text { insects }\end{array}$ & $\begin{array}{l}\text { Both inside and outside } \\
\text { the domain of irregular } \\
\text { flow }\end{array}$ \\
\hline Biological control & $10^{3}$ & $\begin{array}{l}\text { Various factors within the } \\
\text { system }\end{array}$ & $\begin{array}{l}\text { Without obvious } \\
\text { attenuation in the } \\
\text { circulation }\end{array}$ \\
\hline
\end{tabular}

Shenyang city has a serious shortage of water resources. Its water resource per capita is approximately one-fifth of nation's average water supply. To address this challenge, there is a need to understand the interactions between forests and water. The relationship between forest and water is based on the assumption that under any hydrological and ecological circumstance. Forest in upstream has been confirmed that help regulate seasonal flows, maintain water yield and cleanse water quality. Following this assumption, increasing forest cover in upstream of river basin is the best effective measure to ensure high-quality water for agricultural and industrial uses, as well as for residents' drinking-water supply in the downstream areas. As foresters are increasingly 
committed to conservation and construction of forest in the upstream watershed to implement sustainable forest management, it is nearly 2.82 thousand hectare of forest in 2005 , and by 2015 , an additional 4.13 thousand hectare of forest increased, forest cover reaching more than $66 \%$, due to the conservation and construction of forest in the upstream watershed. In addition, there are various types of forests planted in the upstream watershed to maintain a variety of ecological functions. High-quality water obtained by Shenyang city is attributed to a high proportion of the forest cover, various types of forest, and varying ES functions in the upstream.

\section{Data sources}

Forest types from 2010 to 2014were obtained from Fushun and Shenyang Forestry Bureau of Liaoning Province in China. Forest areas in Hunhe River Basin are calculated by studying the land-use map of Liaoning province from 2010 to 2014, the related figures of forest cover comes from Fushun Statistical Yearbooks. The data of water resource data covering stream flow and ground water, chemical oxygen demand (COD) andwater supply come primarily from Shenyang water Resources Bulletin (Shenyang Water Conservancy Bureau, 2010-2014). The standard-reaching rate of water quality is from Liaoning Statistical Yearbooks (Forestry Department of Liaoning Province, 2010-2014).

\section{Assessment of value transfer about forest ES in Hunhe River Basin}

\section{Assessment of forest ecological service value}

There are many ES transferring in space, covering climate regulation, water conservation, soil formation and disposal of waste in the forest ecosystem. Based on the identification that under particular hydrological and ecological circumstance, forest ES in Hunhe River Basin can be defined as the water regulation, water purification, and soil and water conservation in terms of the transfer features and influencing factors in this paper. The forest types in the upstream of the Hunhe River Basin and Shenyang City covers the Querccus, Larix gmelinii, Pinus Koraiensis, Pinus Tabuliformis, Tilia tuan, Pterocarya stenoptera and broad - leaved mixed forest (Table 2).

Table 2. Current situation of forest resources in Hunhe River Basin (Unit:10 ha)

\begin{tabular}{c|c|c|l|c|c|c|c|c}
\hline District & $\begin{array}{c}\text { The } \\
\text { Quercus }\end{array}$ & $\begin{array}{c}\text { Larix } \\
\text { gmelinii }\end{array}$ & $\begin{array}{l}\text { Pinus } \\
\text { koraiensis }\end{array}$ & $\begin{array}{c}\text { Pinus } \\
\text { Tabuliformis }\end{array}$ & $\begin{array}{c}\text { Tilia } \\
\text { tuan }\end{array}$ & $\begin{array}{c}\text { Pterocarya } \\
\text { stenoptera }\end{array}$ & $\begin{array}{c}\text { Broad- } \\
\text { leaved } \\
\text { mixed }\end{array}$ & $\begin{array}{c}\text { In } \\
\text { total }\end{array}$ \\
\hline $\begin{array}{c}\text { Qingyuan } \\
\text { County }\end{array}$ & 12.88 & 10.87 & 0.58 & 0.43 & 0.16 & - & 2.95 & 27.87 \\
$\begin{array}{c}\text { Xinbin } \\
\text { County }\end{array}$ & 15.59 & 7.84 & 0.62 & 0.58 & 0.21 & - & 5.36 & 30.20 \\
$\begin{array}{c}\text { Fushun } \\
\text { County }\end{array}$ & 5.30 & 3.32 & 0.27 & 0.70 & 0.07 & - & 1.78 & 11.44 \\
$\begin{array}{c}\text { Subtotal } \\
\text { Shenyang } \\
\text { City }\end{array}$ & 33.77 & 22.03 & 1.47 & 1.71 & 0.44 & - & 10.09 & 69.51 \\
\hline
\end{tabular}




$$
-474-
$$

Studies have shown that biomass and net primary productivity (NPP) is a key point to assess ES value ( $\mathrm{Li}$ et al., 2015). Total biomass of different types is calculated in the present study based on the formulation given by Fang (Table 3) (1996), and the net primary productivity (NPP) of forests and ES value could be calculated respectively for different forest types (Table 4).

Table 3. Forest ES value provided by different forest types in river basin (Unit: $10^{4} \mathrm{RMB}$, ha)

\begin{tabular}{c|c|c|c|c}
\hline Forest types & $\begin{array}{c}\text { Water } \\
\text { regulation } \\
\text { value }\end{array}$ & $\begin{array}{c}\text { Water } \\
\text { purification } \\
\text { value }\end{array}$ & $\begin{array}{c}\text { Soil and water } \\
\text { conservation }\end{array}$ & $\begin{array}{c}\text { Total value } \\
\text { per hectare }\end{array}$ \\
\hline The Quercus & 0.76 & 0.57 & 0.26 & 1.59 \\
Larix gmelinii & 0.87 & 0.58 & 0.26 & 1.71 \\
Pinus koraiensis & 0.87 & 0.58 & 0.26 & 1.71 \\
$\begin{array}{c}\text { Pinus } \\
\text { tabuliformis }\end{array}$ & 0.87 & 0.55 & 0.26 & 1.68 \\
Tilia tuan & 0.76 & 0.51 & 0.28 & 1.55 \\
$\begin{array}{c}\text { Pterocarya } \\
\text { stenoptera }\end{array}$ & 0.75 & 0.43 & 0.28 & 1.46 \\
$\begin{array}{c}\text { Broad-leaved } \\
\text { mixed forest }\end{array}$ & 0.76 & 0.63 & 0.27 & 1.66 \\
In total & 5.64 & 3.85 & 1.87 & 11.36 \\
Average & 0.81 & 0.55 & 0.27 & 1.62 \\
\hline
\end{tabular}

Notes: ES value of the Quercus, Pterocarya stenoptera and Broad-leaved mixed forest based on the studies given by Baiand Larix gmelinii, Pinus koraiensis, Pinus tabuliformis and Tilia tuan based on the studies given by Ouyang (2011).

Table 4. Relationship between blomas ( $x$ ) and net production (y) for different forest types

\begin{tabular}{c|c|c|c|c}
\hline Forest types & Function expression & $\begin{array}{c}\text { Biomass } \\
(\mathbf{x})\end{array}$ & $\begin{array}{c}\text { Net primary } \\
\text { productivity (NPP, y) }\end{array}$ & $\begin{array}{c}\text { Functional } \\
\text { adjustment } \\
\text { coefficient }\left(\mathbf{K}_{\mathbf{i}}\right)\end{array}$ \\
\hline The Quercus & $\mathrm{y}=8.85$ & - & 8.85 & 0.83 \\
$\begin{array}{c}\text { Larix } \\
\text { gmelinii } \\
\text { Pinus } \\
\text { koraiensis } \\
\text { Pinus } \\
\text { tabuliformis } \\
\text { Tilia tuan }\end{array}$ & $\mathrm{y}=-0.018 \mathrm{x}+14.294$ & 98.74 & 12.52 & 1.18 \\
\hline
\end{tabular}




\begin{tabular}{c|c|c|c|c}
\hline $\begin{array}{c}\text { Pterocarya } \\
\text { stenoptera } \\
\text { Broad- } \\
\text { leaved } \\
\text { mixed forest }\end{array}$ & $1 / \mathrm{y}=12.092 / \mathrm{x}+0.048$ & 268.71 & 10.75 & 1.01 \\
\hline
\end{tabular}

NPP is a good indicator for ecosystem services and biomass, although it is limited by the need. In response to this need for the information on the value of ecosystem services about the impacts, there is a correction factor being applied into this paper (Table 4). $K_{i}$ is computed as:

$$
K_{i}=N P P_{i} / N P P_{\text {mean }}
$$

Where $K_{i}$ is the correction factor; ${ }^{N P P_{i}}$ represents the net primary productivity of forest type $I ;{ }^{N P P_{\text {man }}}$ is average net primary productivity of all forest types.

According to the correction factor of forest ecological service, total values of forest ecosystem are calculated (Table 5) as follows:

$$
V=\sum_{i=1}^{n} \sum_{j=1}^{m} S_{j} E_{i j} K_{i}
$$

Where V represents the ES total value, $i$ is ES type; $j$ is the forest type; ${ }_{j}$ is the forest area of type $j E_{i j}$ is the ESV of $i$ type provided by forest type $j$; parameter ${ }^{K_{i}}$ is the correction factor.

Table 5. ESV both in the upstream and Shenyang city (Unit: $10^{9} \mathrm{RMB}, \mathrm{ha}$ )

\begin{tabular}{c|c|c|c|c}
\hline District & $\begin{array}{c}\text { Water } \\
\text { regulation } \\
\text { values }\end{array}$ & $\begin{array}{c}\text { Water } \\
\text { purification } \\
\text { values }\end{array}$ & $\begin{array}{c}\text { Soil and water } \\
\text { conservation } \\
\text { values }\end{array}$ & Total values \\
\hline $\begin{array}{c}\text { Qingyuan } \\
\text { County }\end{array}$ & 15.97 & 22.54 & 7.29 & 45.80 \\
Xinbing County & 16.79 & 23.10 & 7.62 & 47.51 \\
Fushun County & 6.42 & 8.95 & 2.93 & 18.30 \\
Subtotal & 39.18 & 54.59 & 17.84 & 111.61 \\
Shenyang City & 4.07 & 6.41 & 2.10 & 12.58 \\
\hline
\end{tabular}




\section{Assessment of transfer value for forest ES}

Riparian forests play an important role in regulating water flows and filtering and trapping the sediment and pollutants for ecological environment of river basin. The effectiveness of riparian forests in maintaining downstream water yield and filtering pollutants in a headwater catchment depends on some water-related functions of forest, including water regulation, water purification and soil and water conservation. These services transferred have an impact on the availability and quality of water in Shenyang city. So it is necessary to study the interactive relation between forest and water, for example, assessing effects of transfer value on water quality and quantity.

In geographic theories, the gravity model, breaking-point model and field intensity formula are often introduced to explain the distance attenuation principle and then to calculate transfer value of ES. In 1949, Converse proposed the concept and calculation method of breaking-point (Han et al., 2010). The breaking-point model, which also has been applied in calculation of transfer radium, can't be used in directly and need to be complemented with distance measures from between core point of forest ES in upstream and breaking-point in the downstream areas (Mooi and Sarstedt, 2011). Transfer radium $\mathrm{A}_{i j}$ is calculated as:

$$
A_{i j}=\frac{D_{i j}}{1+\sqrt{V_{j} / V_{i}}}
$$

Where $i, j$ respectively represents the upstream and Shenyang city; $\mathrm{A}_{i j}$ is the transfer radium; ${ }^{V_{i}},{ }_{j}$ is respectively the forest ESV in both upstream and Shenyang city; ${ }^{D_{i j}}$ is the central distance from upstream to Shenyang city.

Transfer value of forest ES is commonly defined as the transposition of monetary ESV estimated through market-based or non-market-based economic valuation techniques. It relies on several factors, including transfer scopes measured with ArcGIS9.3 buffer and overlay analysis platform, central distance between different regions and ESV of affected areas. Transfer value of forest ES can be calculated (Table 6) so described as:

$$
V_{i j}=P_{i j} \frac{V_{j}}{D_{i j}^{2}} S
$$

Where $V_{i j}$ represents the transfer value of forest ES from the upstream to Shenyang city; $S$ is the transfer scopes of forest ES; ${ }^{V_{j}}$ is the forest ESV in Shenyang city, $\mathrm{D}_{i j}$ is the central distance from upstream to Shenyang city; parameter ${ }^{P_{i j}}$ is a some factor, which ensures that medium measure ranges between 0 and 1 , and it is in general 0.6 for ordinal influencing factor. 
Table 6. Transfer value of forest ES from the upstream in Hunhe River Basin from 2010 to 2014 (Unit: $10^{9} \mathrm{RMB}, \mathrm{ha}$ )

\begin{tabular}{c|c|c|c|c}
\hline Years & $\begin{array}{c}\text { Water } \\
\text { regulation }\end{array}$ & $\begin{array}{c}\text { Water } \\
\text { purification }\end{array}$ & $\begin{array}{c}\text { Soil and water } \\
\text { conservation }\end{array}$ & $\begin{array}{c}\text { Total } \\
\text { values }\end{array}$ \\
\hline 2010 & 5.51 & 3.50 & 1.80 & 10.81 \\
2011 & 5.52 & 3.51 & 1.81 & 10.84 \\
2012 & 5.65 & 3.59 & 1.85 & 11.28 \\
2013 & 5.88 & 3.75 & 1.93 & 11.60 \\
2014 & 6.08 & 3.87 & 1.99 & 11.94 \\
\hline
\end{tabular}

\section{Path analysis about effect of transfer value on water supply}

Path analysis method is to analyze the relations between two variables by decomposing the correlation coefficient, and then express the direct effect of an independent variable on the dependent variable, and the indirect effect of an independent variable on the dependent variable caused by other variables ( $\mathrm{Fu}, 2014)$.

Path coefficient is an important indicator for the path analysis to reasonably explain the complex relationship between variables, including direct path coefficient and indirect path coefficient. Direct path coefficient is to describe the influence of independent variable itself on dependent variable, while indirect path coefficient aims at analyzing the effects of independent variable on dependent variable by others. Path analysis is expressed by the measuring models in the following equations:

$$
\left\{\begin{array}{l}
a_{1}+r_{12} a_{2}+\ldots \ldots+r_{1 p} a_{p}=r_{1 y} \\
r_{21} a_{1}+b_{2}+\ldots \ldots+r_{2 p} a_{p}=r_{2 y} \\
r_{p 1} a_{1}+r_{p 2} a_{2}+\ldots \ldots .+a_{p}=r_{p y}
\end{array}\right.
$$

Where $a_{i}$ is the partial regression coefficient for variable $i ; r_{i j}$ is the correlation coefficient between $x_{i}$ and $x_{j} ; r_{i y}$ is the correlation coefficient between $x_{i}$ and $y, i, j=1,2, \ldots, p$.

As is shown in Equation (5), $a_{i}$ is the direct effect of ${ }^{x_{i}}$ on $y$, namely ${ }^{x_{i}}$ is also the direct path coefficient for ${ }^{y} ; r_{i j} a_{j}$ is the indirect effect of $x_{i}$ on $y_{\text {by }} x_{j}\left(x_{i} \leftrightarrow x_{j} \rightarrow y\right)$, namely $r_{i j} a_{j}$ is also the indirect path coefficient for $y_{\text {by }} x_{j} . r_{i j} a_{j}$ can be calculated so described as:

$$
r_{i y}=a_{i}+\sum_{j=1} a_{j} r_{i j}
$$


In path analysis, the coefficient of determination called ${ }^{2}$ indicates the effect of independent variables on dependent variable. If the coefficient of determination is significant, the path analysis is valid, otherwise it is meaningless. ${ }^{R_{(i)}}{ }^{2}$ is calculated as follows:

$$
R^{2}=\sum_{i=1}^{p} R_{i}^{2}+\sum_{i<j}^{p-1} R_{i j}^{2}=\sum_{i=1}^{p} b_{i} r_{i y}
$$

Where $R_{i}^{2}$ is the coefficient of direct determination for effect of ${ }^{x_{i}}$ on ${ }^{y}$, namely $R_{i}^{2}=a_{i}^{2} ; R_{i j}{ }^{2}$ is the coefficient of indirect determination for effect of ${ }^{x_{i}}$ on $y$ by ${ }^{x_{j}}$;

Path analysis has been commonly applied to studying the direct and indirect effect of independent variables on dependent variable, but it is very difficult to identify which independent variable plays the most important role for dependent variable. So decision coefficient is introduced in this paper. Compared with the coefficient of determination, value of decision coefficient can order the potential combined effects of independent variable on dependent variable. The independent variable of the first order is the most critical decision one, but it does not mean that independent variable of last order has no effect. If decision coefficient is negative, it shows that independent variables have restrictive effect on dependent variable (Yuan et al., 2011). ${ }^{R_{(i)}{ }^{2}}$ is calculated as follows:

$$
R_{(i)}^{2}=a_{i}^{2}+2 \sum_{j \neq i} a_{i} r_{i j} a_{j}=R_{i}^{2}+\sum_{j \neq i} R_{i j}^{2}
$$

Where $R_{i}^{2}$ is the coefficient of direct determination for effect of ${ }^{x_{i}}$ on $y ; R_{i j}{ }^{2}$ is the coefficient of indirect determination for effect of ${ }^{x_{i}}$ on $y$ by ${ }^{x_{j}} ;{ }^{a_{i}}$ is the direct path coefficient for the direct effect of ${ }^{x_{i}}$ on ${ }^{y} ;{ }_{i j} a_{j}$ is the indirect path coefficient for the indirect effect of ${ }^{x_{i}}$ on $y_{\text {by }} x_{j}$.

In a word, the path analysis aims at analyzing the direct, indirect and comprehensive effect of independent variable on the dependent variable by the direct and indirect path coefficient and decision coefficient, based on building the regression equation.

\section{Econometric model}

Choice of influencing factors about water supply in Shenyang city

Although the relationship between forests and water is a complex issue, forest ES plays an important role in improving ecological environment of water resources, which are mainly attributed to water regulation, water purification and soil and water conservation. Water regulation is deemed that water resource is redistributed by 
maintaining or regulating hydrological flows and runoff recharging. Water purification aims at cleansing water quality. This is achieved through reduction of excessive concentrations of organic matter and filtering various types of pollutants in water bodies. Soil and water conservation is generally associated with prevention of soil erosion and with maintaining water resources. The surface cover, debris and tree roots are more effective in keeping the water. Moreover, the role of the upstream forests in regulating water flows, purifying water quality of the upper watershed and supplying water in downstream areas cannot be ignored. To analyze this effect under particular hydrological and ecological circumstance, water-related ecological system will be introduced in river basin. This system of water supply comprises two major activities: ecological production and stream flow/natural water (Matete and Hassan, 2006). Ecological production refers to transfer value of forest ES $\left(\mathrm{X}_{1}\right)$, and stream flow or natural water includes water quantity and water quality, consisting of stream flow and groundwater $\left(\mathrm{X}_{2}\right)$, chemical oxygen demand $(\mathrm{COD})\left(\mathrm{X}_{3}\right)$ and the standard-reaching rate of water quality $\left(\mathrm{X}_{4}\right)$ in this paper (Table 7$)$.

Table 7. Influencing factors of water supply in Shenyang city from 2010 to 2014

\begin{tabular}{|c|c|c|c|c|c|}
\hline Year & $\begin{array}{c}\text { Transfer value } \\
\text { of forest ES } \\
\left(10^{9} \mathrm{RMB}\right)\end{array}$ & $\begin{array}{l}\text { stream flow and } \\
\text { groundwater } \\
\left(10^{9} \mathrm{~m}^{3}\right)\end{array}$ & $\begin{array}{c}\text { COD } \\
\left(10^{5} \mathrm{~m}^{3}\right)\end{array}$ & $\begin{array}{c}\text { Standard- } \\
\text { reaching rate of } \\
\text { water quality }(\%)\end{array}$ & $\begin{array}{l}\text { Water } \\
\text { supply } \\
\left(10^{9} \mathrm{~m}^{3}\right.\end{array}$ \\
\hline 2010 & 10.81 & 46.40 & 0.95 & 94.86 & 28.40 \\
\hline 2011 & 10.84 & 45.44 & 0.94 & 95.89 & 28.43 \\
\hline 2012 & 11.28 & 47.71 & 0.93 & 99.50 & 28.76 \\
\hline 2013 & 11.60 & 47.71 & 0.92 & 97.64 & 28.98 \\
\hline 2014 & 11.94 & 48.19 & 0.94 & 100.00 & 29.00 \\
\hline
\end{tabular}

Table 8. Correlation coefficient between water supply and influencing factors

\begin{tabular}{c|c|c|c|c|c|c}
\hline Variables & $\boldsymbol{X}_{\mathbf{1}}$ & $\boldsymbol{X}_{\mathbf{2}}$ & $\boldsymbol{X}_{\mathbf{3}}$ & $\boldsymbol{X}_{\mathbf{4}}$ & $\boldsymbol{Y}$ & Sig. \\
\hline$X_{1}$ & 1.0000 & 0.8897 & -0.4864 & 0.8383 & 0.9694 & 0.0064 \\
$X_{2}$ & 0.8897 & 1.0000 & -0.4915 & 0.8449 & 0.9076 & 0.0333 \\
$X_{3}$ & -0.4864 & -0.4915 & 1.0000 & -0.4695 & -0.6769 & 0.2094 \\
$X_{4}$ & 0.8383 & 0.8449 & -0.4695 & 1.0000 & 0.8285 & 0.0830 \\
$Y$ & 0.9694 & 0.9076 & -0.6769 & 0.8285 & 1.0000 & 0.0001 \\
\hline
\end{tabular}

\section{Correlation analysis}

Correlation analysis is often used to describe the degree of linear correlation among the variables. Although the methods of correlation analysis are various, many studies often rely on the correlation coefficient as an important indicator for measurement of linear correlation among the variables (Zhu et al., 2008). Pearson's correlation 


$$
-480-
$$

coefficient was applied to analyze the relationship between the influencing factors and water supply of Shenyang city (Table 8). The purpose of correlation analysis is to do some preliminary analysis on the relationship among variables and to prepare for building the model (Zhang et al., 2012).

As is shown in Table 8, correlation coefficient between $\mathrm{X}_{\mathrm{i}}$ and $\mathrm{Y}$ showsthe ordering: $\mathrm{Px}_{1}>\mathrm{Px}_{2}>\mathrm{Px}_{4}>\mathrm{Px}_{3}$. The results implies that water $\operatorname{supply}(\mathrm{Y})$ is significantly influenced by transfer value of forest $\operatorname{ES}\left(\mathrm{X}_{1}\right)$. In addition, it indicates that it is negative correlation between chemical oxygen demand (COD) $\left(\mathrm{X}_{3}\right)$ and water supply $(\mathrm{Y})$, and positive correlation between water supply $(\mathrm{Y})$ and transfer value of forest $\mathrm{ES}\left(\mathrm{X}_{1}\right)$, stream flow and groundwater $\left(\mathrm{X}_{2}\right)$ and standard-reaching rate of water quality $\left(\mathrm{X}_{4}\right)$.

\section{Regression model}

In order to facilitate analysis and explanation, the econometric model is built based on the chosen explanatory variables by means of multiple linear stepwise regressions. Specific calculations are completed by the SPSS17.0. The econometric model is intended to be constructed as follows:

$$
Y=0.497 X_{1}-6.818 X_{3}+29.486
$$

Where $Y$ is the water supply in Shenyang city, $X_{1}$ and $X_{3}$ are the variables of transfer value of forest ES and chemical oxygen demand respectively. The result and test values of this are shown in Table 9.

\begin{tabular}{|c|c|c|c|c|}
\hline Variables & Coefficients & $\mathbf{t}$ & Sig. & Collinearity \\
\hline Constant & 29.485 & 18.612 & 0.003 & - \\
\hline $\begin{array}{l}\text { Transfer value of } \\
\text { forest ES }\end{array}$ & 0.497 & 14.608 & 0.005 & 1.310 \\
\hline $\begin{array}{c}\text { Chemical oxygen } \\
\text { demand }\end{array}$ & -6.818 & -4.687 & 0.043 & 1.310 \\
\hline
\end{tabular}

Table 9. The result and test values for influencing factors of water supply

Notes: $\mathrm{R}=0.997 ; \mathrm{R}^{2}=0.995 ; \mathrm{F}$ (sig.) =197.793(0.05); Durbin-Watson $\mathrm{d}=2.8335$

As is shown from Table 9, only the variables, 'transfer value of forest ES' and 'chemical oxygen demand', have passed the $\mathrm{F}$ test and $\mathrm{t}$ test excluding the other variables- 'stream flow and groundwater' and 'standard-reaching rate of water quality'. The goodness-of-fit of this model is satisfactory.

Table 10. Analysis of path correlation between water supply and influencing factors

\begin{tabular}{ccccccc}
\hline Variables & Direct effect & $\rightarrow \boldsymbol{X}_{\mathbf{1}}$ & $\boldsymbol{\rightarrow} \boldsymbol{X}_{\mathbf{3}}$ & $\begin{array}{c}\text { Indirect } \\
\text { effect }\end{array}$ & Total effect & $\begin{array}{c}\text { Decision } \\
\text { coefficient }\end{array}$ \\
\hline$X_{1}$ & 0.8385 & - & 0.1309 & 0.1309 & 0.9694 & 0.9226 \\
$X_{3}$ & -0.2691 & -0.4079 & - & -0.4079 & -0.6770 & 0.2919 \\
\hline
\end{tabular}


The results of the model have further verified the previous inference from qualitative analysis. Transfer value of forest ESplays an important roleas an influencing factor which can regulate the recharging of groundwater aquifers and improve the function of the hydrologic cycle. However, stream flow and groundwater as the critical resource capturing and processing energy to provide water for Shenyang city is excluded in the model, it indicates that this variable has not mainly linear relationship. In another word, it cannot significantly increase water yield. Because several natural factors are alteringforest's role in influencing the availability of water resources (Bergkamp et al., 2003; Balkhair, 2016; Wu and Feng, 2016; Meng et al., 2016; Zhang, 2013), including other meteorological variables (precipitation and temperature). Chemical oxygen demand (COD) is regarded as a critical indicator to impair water quality. Because potential pollutants come from agricultural or industrial chemicals and domestic sewage, excessive concentrations of organic matter have greatly negativeeffect on drinking-water-supply. Adequate riparian forest buffer zones along watercourses can be maintained, which helps protect water and soils and even reduce pollutants flowing to rivers so as to decrease chemical oxygen demand (COD) and cleanse water quality. So the results show that the delivery of high-quality water can be ensured by the upstream forest, but the benefits of the upstream forest on increasing downstream water yield were generally misleading. This conclusionis the same as the results confirmed by FAO and CIFOR (2005).

\section{Path analysis}

Based on the above econometric model, this part is to explain the effects of transfer value of forest ES in the upper watershed on water supply in Shenyang city by the means of path analysis.

It can be seen from Table 10 that the decision coefficients of 'transfer value of forest ES' and 'chemical oxygen demand (COD)' to water supply in Shenyang city are 0.9226 and 0.2919 respectively, which shows that the former affects water supply in Shenyang city more significantly than the latter. Besides, the former produces positively indirect influence on water supply, while the latter has negatively indirect influence.

Forest ES in the upper watershed provides valuable regulating services for drinkingwater-supply of the downstream. It mitigates water pollution by preventing excessive concentrations of organic matter from directly reaching the sea and the nearby beaches.

When it rains, canopy layer intercept the precipitation, it is under the action of gravity that water flows into the soil carrying large amounts of nutrients can be absorbed, regulated and redistributed by forest ES functions, which produces the stream flow and groundwater. Meanwhile, in the cyclic process of hydrological and ecological circumstancevarious chemicals can be filtered in water bodies and chemical oxygen demand is gradually reduced to prevent pollutants from reaching the streams. When rivers are carriers of nutrients and pollutants, the reduction of sediment delivered to streams has a positive impact on water quality of the downstream and the livelihoods and health of downstream populations. So the transfer value of forest ES from the upper watershed not only regulate seasonal availability of water, but also cleanse water quality for Shenyang city. 


\section{Conclusion}

Undoubtedly, transfer value of forest ES undoubtedly has a significant impact on water supply in Shenyang city directly and indirectly. Main conclusions are as follows:

(1) Forest ES values are 111.61 billion RMB and 12.58 billion RMB respectively in the upstream and Shenyang city. With forest resources as the medium, transfer value have reached 56.57 billion RMB between the upstream and Shenyang city from 2010 to 2014, in addition to meet its own need for forest ES.

(2) Transfer value of forest ES has been identified as an important factor of water supply. According to the results of econometric models, it is largely correlated with each other. Therefore, transfer value of forest ES is not only an essential assurance for Shenyang city to share the balanced and sustainable availability of water resources, but also an effective guarantee to provide benefits to the urban populations in terms of highquality drinking water.

(3) This results further carry out preliminary discussion about the influence of transfer value of forest ES on regulating water and cleansing water quality by the path analysis. It produces the positive externalities, which is beneficial to the stakeholders and greatly promotes formulation and implementation of ecological compensation policy and the coordinated and sustainable development among some districts.

\section{Discussion}

We have attempted to assess the transfer value of forest ES in the upper watershed, and have described its effect on water supply in river basin areas by the path analysis method. From this analysis it shows that there are some critical theoretical and empirical issues that remain to be resolved.

(1) According to the existing research results, forest ESV was used to statically evaluate by the market value method, production cost method and opportunity cost method, which only measure ESV in a certain region, but not calculate the spillover value of forest ES to other regions. In this paper, in addition to meet its own need for forest ES measured, the spillover value of forest ES can be still dynamically calculated from the upstream to the downstream in Hunhe River Basin with the help of Buffer and Intersect of ArcGIS9.3. The results are important proofs of payment for ecological services in the theory.

(2) The relation between transfer values of forest ES and water supply is very complex. At present, most of the research results focus on precipitation input, runoff output and the change of element content in the system cycle, but the interaction of each factor and a certain factor indirectly influenced by others may be ignored in forest hydrological process. The path analysis demonstrates that forest ESV from the upstream produces direct and indirect impacts on water resource from downstream in the river basin. Due to limited data, the impact of transfer value of forest ES on water resources is also affected by other factors, which needs further study in the future. 


$$
-483-
$$

(3) Forest ES are affected by many factors that are different in different regions, including light and heat, precipitation and site conditions. While these are beyond the scope of this paper, our analysis only can serve as a useful starting point, and these factors could be considered in further study.

\section{REFERENCES}

[1] Bai, Y., Ouyang, Z. Y., Zheng, H. et al. (2011): Evaluation of the forest ecosystem services in Haihe River Basin, China. - Acta Ecologica Sinica 31 (7): 2029-2039.

[2] Bateman, I. J., Brainard, J. S., Lovett, A. A. (1995): Modelling woodland recreation demand using geographical information systems: a benefits transfer study. Global Environmental Change Working Paper 95-06., Centre for Social and Economic Research on the Global Environment (CSERGE), University College London and University of East Anglia, Norwich.

[3] Balkhair, K. S. (2016): Microbial contamination of vegetable crop and soil profile in arid regions under controlled application of domestic wastewater. - Saudi Journal of Biological Sciences 23 (1): 83-92.

[4] Bergkamp, G., Orlando, B., Burton, I. (2003): Change: adaption of water resources management to climate change. Gland, Switzerland, World Conservation Union (IUCN).

[5] Brouwer R. (2000) Environmental value transfer: State of the art and future prospects. Ecological Economics 32: 137-152.

[6] Bruijnzeel, L. A. (2004): Hydrological functions of tropical forests: not seeing the soil for the trees? - Agriculture, Ecosystems and Environment 104: 185-228.

[7] Bu, H. M., Dang, H. S., Zhang, Q. F. (2010): Impacts of forest vegetation on water environment of the Jinshui River Basin in the Upper Han River. - Acta Ecologica Sinica 30 (5): 1341-1348.

[8] Calder, I. R. (2007): Forests and water-ensuring forest benefits outweigh water costs. Forest Ecology and Management 251: 110-120.

[9] Carson, R. T. (2000): Contingent Valuation: A User's Guide. - Environmental Sciences and Technology 34: 1413-1418.

[10] Chaikumbung, M., Doucouliagos, C., Scarborough, H. (2016): The economic value of wetlands in developing countries: a meta-regression analysis. - Ecol. Econ. 124: 164-174.

[11] Chen, J. L., Xu, M. Y., Su, X. et al. (2014): Spatial transfer of regional ecosystem service in Nanjing City. - Acta Ecologica Sinica 34 (17): 5087-5095.

[12] Costanza, R., Arge, R., Groot, R. et al. (1997): The value of the world's ecosystem services and natural capital. - Nature 386: 253-260.

[13] Daily, G. (1997): Nature's service: Societal Dependence on Natural Ecosystems. Washington DC: Island Press.

[14] Dou, W, Shi, P. J., Chen, Y. Q. et al. (2003): Analysis and discussion of the static partial equilibrium model for the valuation of the ecosystem capital. - Journal of Natural Resources 18 (5): 626-634.

[15] Egoh, B., Rouget, M., Reyers, B. et al. (2007): Integrating ecosystem services into conservation assessment: A Review. - Ecological Economics 63 (4): 714-721

[16] Fan, X. S., Gao, J. X., Wen, W. (2007): Exploratory Study on Eco-Assets Transferring and the Valuating Models. - Research of Environmental Sciences 20 (5): 160-164. 
[17] Fang, J. Y., Liu, G. H., Xu, S. L (1996): Biomass and net production of forest vegetation in China. - Acta Ecologica Sinica 16 (5): 497-508.

[18] FAO \& CIFOR. (2005): Forests and floods: drowning in fiction or thriving on facts? RAP Publication 2005/03. Bangkok, Thailand, FAO Regional Office for Asia and the Pacific.

[19] Fu, L. L., Deng, Q. Z., Weng, Y. J. (2014): The Transmission of International Crude Oil Price Fluctuations to Domestic Prices of Agricultural Product Based on Path Analysis. Resource Science 36 (7): 141

[20] Groot, R. (2002): A typology for the classification description and valuation of ecosystem functions, goods, and service. - Ecological Economics (40): 393-408.

[21] Han, Y. W., Gao, X. T., Gao, J. X. (2010): Typical ecosystem services and evaluation indicator system of significant eco-function areas. - Ecology and Environmental Sciences 19 (10): 2986-2992.

[22] Hanemann, W M. (1994): Valuing the Environment Through Contingent Valuation, Federal Register 58: 4602-4614.

[23] Hu, H S. (2007): Evaluation of the Service Value of the Forest Ecosystem in Lushan Mountain Nature Reserve. - Resource Science 29 (5): 29-36.

[24] Huang, L Y, Yan, Q L, Gao, T. et al. (2015): Estimation on stock volume of plantation forests using ALOS PALSAR images: A case study of Larix principis-rupprechtii plantations in Saihanba Forest Farm. - Chinese Journal of Ecology 34 (9): 2401-2409.

[25] Li, W. K., Guo, Q. H. (2013): How to assess the prediction accuracy of species presenceabsence models without absence data? - Ecography 36 (7): 788-799.

[26] Li, W.H., He, Y.T., Yang, L.Y. (2001): A summary and perspective of forest vegetation impacts on water yield. - Journal of Nature Resources 16 (5): 398-406.

[27] Liao X C, Xia E L, Wang Z F. (2016): The impact of increasing block water tariffs on residential water usage and the welfare of low income families in Chinese cities. Resources Science 38 (10): 1935-1947.

[28] Li, X.S., Zhu, Y.M., Zhao, L. et al. (2015): Ecosystem services value change in Qinglong County from dynamically adjusted value coefficients. - Chinese Journal of EcoAgriculture 23 (3): 373-381.

[29] Liaoning Statistical Yearbooks (2010-2014): Forestry Department of Liaoning Province.

[30] Luken, R. A., Johnson, F. R., Kibler, V. (1992): Benefits and costs of pulp and paper effluent controls under the Clean Water Act. - Water Resour. Res. 28(3) 665-674.

[31] Matete, M., Hassan, R. (2006): Integrated ecological economics accounting approach to evaluation of inter-basin water transfers: An application to the Lesotho Highlands water Project. - Ecological Economics 60: 246-259.

[32] Meng, F. X. et al. (2016): The optimization of Marasmius androsaceus submerged fermentation conditions in five-liter fermentor. - Saudi Journal of Biological Sciences 23 (1): 99-105.

[33] Millennium Ecosystem Assessment (2003): Ecosystems and Human Well-being: A Framework for Assessment. - Washington DC: Island Press.

[34] Mooi, E., Sarstedt, M. (2011): A concise guide to market research. Chapter 9 Cluster Analysis. - Springer-Verlag, Berlin Heidelberg, 237-284.

[35] Paula, B. M., Oscar, M. N. (2012): Land-use Planning Based on Ecosystem Service Assessment: A Case Study in the Southeast Pampas of Argentina. - Agriculture, Ecosystems and Environment 154: 34-43. 
[36] Portney, P. R. (1994): The Contingent Valuation Debate: Why Economists Should Care, - Journal of Economic Perspectives 8 (4): 3-15.

[37] Qiao, X. N., Yang, Y. J., Yang, D. G. (2011): Assessment of Ecosystem Service Value Transfer in Weigan River Basin, Xijiang, China. - Journal of Desert Research 31 (4): 1008-1014.

[38] Shenyang Water Resource Bulletin (2010-2014): Shenyang Water Conservancy Bureau.

[39] Van Dijk, A. I. J. M., Keenan, R. (2007): Planted forests and water in perspective. Forest Ecology and Management 251 (1-2): 1-9.

[40] Wallace, K. J. (2007): Classification of ecosystem services: problems and solutions. Biological Conservation 139: 235-246

[41] Wu, K., Feng, Q. L. (2016): Understanding of gas storage and migration pathways in shales: Example from pore characteristics of gufeng formation. - Journal of Mechanical Engineering Research and Developments 39 (2): 394-402.

[42] Xiao, Q., Xiao, Y., Ouyang, Z. Y. (2014): Value assessment of the function of the forest ecosystem services in Chongqing. - Acta Ecological Sinica 34 (1): 216-222.

[43] Xie, G. D., Zhang, C. X., Zhang, C. S. et al. (2015): The value of ecosystem services in China. - Resources Science 37 (9): 1740-1746.

[44] Xie, G. D., Lu, C. X., Chen, S. K. (2011): Progress in Evaluating the Global Ecosystem Services. - Resource Science 23 (6): 5-9.

[45] Xu, D. W., Zhao, Y. .F, Hou, T. S. et al. (2015): An Empirical Analysis on the Disparities of WTP and WTA in Ecological Value Assessment of Liaohe River Basin. - Journal of Applied Statistics and Management 34 (1): 29-37.

[46] Yuan, Z. F., Zhou, J. Y., Guo, M. C. et al. (2011): Decision coefficient-the decision index of path analysis. - Jour. of Northwest Sci-Tech Univ. of Agri. and For. (Nat. Sci. Ed.) 29 (5): 131-133.

[47] Zhang, Y. M.(2012): Some Basic Issues in Ecosystem Services Research. - Resources Science 34 (4): 725-733.

[48] Zhang, W., Zhang, H. Y., Zhang, Y. F. (2012): A method to determine the spatial allocation standard of social ecological compensation. - Journal of Geographical Sciences 22 (2): 283-300.

[49] Zhang, Z. X. (2013): Research on evaluation of forest ecosystem services in Wulingshan natural reserve of Hebei province. Beijing Forestry University.

[50] Zhen, H. X. (2006): Study on Compensation Mechanism and Policy of Ecological Service in Chinese Watershed, Chinese Academy of Agricultural Sciences.

[51] Zhou, J. X., Peng, Z. H., Li, S. D. (2002): The Relationship Between Forestry EcoEngineering and Water Resource Exploitation and Utilization. - World Forestry Research 15 (6): 54-60.

[52] Zhu, J. B., Yang, W. P., Su, W. M. (2008): Analysis of the driving influence mechanism of Linli County Based on the multiple Regression Analysis Law and the Latus Rectum Analysis. - Economic and Geography 28 (3): 488-491. 